\title{
КЛІНІЧНЕ ВИМІРЮВАННЯ ІНДЕКСІВ ЗНОСУ ЗУБІВ. ТЕОРЕТИЧНИЙ Огляд
}

\author{
Національний медичний університет імені О.О. Богомольця, м. Київ, Україна
}

Виснаження, ерозії і стирання проявляються у вигляді зносу зуба. Кожна класифрікація відповідає різним процесам 3 конкретними клінічними ознаками. Класифікації, які представлені на даний час, не мають точних даних про поширеність зносу зубів, оскільки індекси не завжди вимірюють специфічну етіологію, або тому, що популяції дослідження можуть бути найрізноманітнішими за віком і характеристиками. Знос зубів (потертість, ерозії і стирання) розглядається на міжнародному рівні як зростаюча проблема. Існують як клінічні, так і наукові потреби виміряти знос зуба, і в літературі описано багато методів, які можна умовно розділити на кількісні та якісні. Проте інтерпретувати і порівнювати клінічні та епідеміологічні дослідження стає дедалі важче через відмінності в термінології і велике число індикаторів/показників, які було розроблено для діагностики, класифрікації та моніторингу втрати твердих тканин зуба. Ці показники розроблено з метою виявлення підвищення точності, але ніхто не має загального визначення, що ускладнює оцінку істинного збільшення розповсюдження. У літературі визначено різні показники для використання в клінічних та лабораторних умовах специфічних показників для стирання, зносу, ерозії зуба.

Мета - аналіз спеціалізованої наукової літератури для узагальнення даних про погляди на етіологію та методи дослідження показників стертості зубів.

Матеріали і методи. Вивчили та проаналізували доступну наукову літературу, присвячену особливостям етіопатогенезу, клінічного перебігу і методам дослідження показників стертості зубів.

Результати. Вивчивши і проаналізувавши спеціалізовану наукову літературу, виявили, що існує досить багато поглядів щодо етіології та методів дослідження індексів стертості зубів. Наявні як клінічні, так і наукові потреби виміряти знос зуба. Не існує ідеального індексу, який буде простим для використання і розуміння та підрахунку критеріїв.

Висновки. Існує дуже багато індексів, які запропоновано і використано, з відсутністю стандартизації в термінології. На сьогодні не існує ідеального індексу, який може бути застосований при проведенні епідеміологічних досліджень, а також необхідно визнати, що немає показника, щоб задовольнити всі вимоги клінічних дослідницьких груп. Поточні діагностичні критерії різних фрорм зносу зубів не точні, тому є необхідність виконання подальших досліджень.

КЛЮчОВІ СЛОВА: знос зуба; показники зносу зуба; стертість; ерозії; абфракція.

Знос зуба може бути класифікований як потертість, ерозії і стирання. Виснаження визначається як втрата емалі, дентину або реставрації контакту зуб до зуба. Ерозія - втрата твердих тканин зуба шляхом хімічного впливу, не пов'язаних з бактеріями. Вона класифікується, відповідно до джерела кислоти, як внутрішня і зовнішня. Внутрішні джерела кислот виникають у шлунку і пов'язані 3 розладами харчової поведінки, такими, як анорексія та булімія, кислотний рефлюкс і регургітація. Зовнішні джерела кислоти містяться в харчових компонентах, таких, як газовані напої і фррукти, а також фрруктові соки [1]. Стирання - втрата твердих тканин зуба за рахунок контакту з іншими зубами. У 1908 p. Black у своїй праці 3 хірургічної стоматології обговорив проблему етіології, він назвав їі «ерозія» і заявив, що «Наша інформація щодо ерозії далека від досконалості, й багато часу може пройти, перш ніж ії дослідження дасть задовільні результати» [2]. Після розгляду кожної (c) А.О. Щербенко, 2017 гіпотези, у свою чергу, він дійшов висновку, що в нього не було ніяких власних теорій, щоб запропонувати, які б мали якісь особливості. Інші дослідники на початку XX століття також розглянули ці ураження [3]. У минулому столітті багато авторів описувало цей тип травми, не маючи змоги запропонувати розумне пояснення [4], в 1932 р. Корнфельд зробив спостереження, що у всіх пацієнтів з ерозією в пришийковій ділянці було виявлено межі зносу на жувальних поверхнях зубів, які розташовувались один навпроти одного [5]. Збиває 3 пантелику використання терміна «ерозії», щоб описати ураження, яке насправді може бути викликане механічним або хімічним чинником, описаним стоматологами як корозія [6]. Ця неточна термінологія утруднювала проведення високоякісних досліджень і встановлення точних діагнозів, що дозволило рекомендувати відповідні процедури. Багато практичних лікарів вважало, що інтенсивне чищення зубів і використання абразивних зубних паст були основною причиною 
цих ушкоджень, але Lee i Eakle висунули гіпотезу про те, що тиск, створений у зубі під час оклюзійного навантаження, може відігравати певну роль в етіології ураження [7]. Вони описали три типи стресу, який виникає на зубах під час жування та порушення фрункції: 1) при стисненні: опір стисненню; 2) при розтягуванні: опір розтягуванню; 3) зсув: стійкість до ковзання. Автори стверджують, що до «неідеальності» оклюзії можуть призводити великі бокові сили, які будуть посилювати тиск на стороні навантаженого зуба і передавати напругу в протилежну сторону. Добре відомо, що емаль міцна при стисненні, але слабка до напруги, висловлено припущення про те, що такі ділянки при розтягуванні схильні до ураження. Ділянка найбільшої напруги розміщена в точці прикріплення зуба. Характерне ушкодження було описано як клиноподібне 3 гострими кутами лінії, яке розташоване на або поблизу точки прикріплення зуба, де генерується найбільше напруження. Висловлено думку про те, що напрямок поперечної сили регулюється положенням осередку ураження і його розмір пов'язаний з величиною і тривалістю сили. Grippo запропонував нову класифрікацію уражень твердих тканин зубів [8]. Він визначив чотири категорії зносу зуба:

1. Виснаження: втрата тканини зуба в результаті контакту одного зуба з іншим при нормальній або парафрунцціональній активності.

2. Садна: патологічний знос тканини зуба внаслідок впливу біомеханічних чинників, наприклад чистка зубів.

3. Ерозія: втрата тканини зуба шляхом кислотного розчинення, внутрішнього чи зовнішнього походження, наприклад кислоти шлункового соку або харчових кислот.

4. Абфрракція: патологічна втрата тканин зуба, викликана біомеханічним навантаженням. Було припущено, що ці ушкодження спричинені вигином зуба під час завантаження, що призводить до втоми емалі та дентину в розподілі навантаження. Слово «абфракція» походить від латинського «відірватися». Grippo потім продовжив далі описувати п'ять категорій абфракції: мікротріщини, виникнення смужок (горизонтальні смуги на емалі), блюдця (ураження повністю в межах емалі), півмісяцеподібну фрорму (у фрормі півмісяця ураження повністю в межах емалі) і параболічні впинання вершин (заглиблення на вершини горба спостерігалось на молярах і премолярах). Lambert i Lindenmuth вважали, що головними в розвитку пришийкових уражень були професійні чинники, які значною мірою впливають на оклюзійні ушкодження [9]. На сьогодні практичні лікарі визнають, що абфракція належить до атипових оклюзійних навантажень, незважаючи на брак доказів, які базуються тільки на теоретичній частині цієї гіпотези.
Мета роботи - аналіз спеціалізованої наукової літератури для узагальнення даних про погляди на етіологію та методи дослідження індексу стертості зубів.

Матеріали і методи. Існують як клінічні, так і наукові потреби виміряти знос зуба, і в літературі описано багато методів, які можна умовно розділити на кількісні та якісні. Кількісні методи, як правило, базуються на об'єктивних фрізичних вимірюваннях, таких, як глибина канавки, площа фрасетки або висота коронки. Якісні методи, основані на клінічних описах, можуть бути більш суб'єктивними, в яких корисні епідеміологічні методи [10]. При клінічному внутрішньоротовому обстеженні краще описувати перебіг (слабкий, помірний або тяжкий), а не проводити кількісного виміру, який надійніше виконувати на моделі або в лабораторії. Такі методи, як правило, більш точні, але не завжди знаходять клінічне застосування, особливо в галузі епідеміології, де збір даних часто здійснюють без потрібного обладнання. Кількісні та якісні методи зазвичай використовують для виявлення наростання тяжкості або прогресування стану; вони описуються як індекси та чисельність. Ідеальний індекс повинен бути простим для розуміння і використання, зрозумілим у підрахунку критерієм і явно відтвореним. Його застосування має бути корисним для досліджень етіології, профрілактики і моніторингу ураження, по суті будучи епідеміологічним та клінічним інструментом [11].

Результати дослідження та їх обговорення. Огляд літератури показує той фракт, що багато різних показників зносу зуба було розроблено для клінічного і лабораторного використання у всьому світі. На жаль, багато показників не дозволяє порівняти результати між різними робочими групами, і це особливо важливо в епідеміології при спробі визначити поширеність ураження [12]. Додатково заплутує більшість дослідників, які у своїх спробах визначити кількість втрати тканин зуба через зношування зуба історично зосереджені тільки на одній етіології, але ці показники поверхневі. Часто описаний знос твердих тканин не відтворюється в характерній для нього етіології, це пов'язано 3 відсутністю однаковості термінології зносу твердих тканин зуба і допущення помилок. Багато діагностичних показників не відображає належним чином морфологічних десектів [13]. Усі ці фрактори ускладнюють порівняння даних і оцінки ефективності профрілактичних і лікувальних заходів. У літературі визначено різні показники для використання в клінічних та лабораторних умовах специфічних показників для стирання, зносу, ерозії зуба. $€$ загальні значення для всіх індексів, такі, як описові діагностичні критерії і критерії для визначення кількості втрати твердих тканин. Вони, як правило, враховують розмір ураженої ділянки 
(глибину втраченої тканини), що часто виражається як ступінь ураження дентину. Визнано вплив дентину як індикатора для істотної втрати тканини зуба [14]. Проте ураження дентину призводить до розкриття постійних зубів у молодому віці. Smith i Knight представили більш загальну концепцію вимірювання зубів, вони стверджували, що зуби зношуються самі по собі, незалежно від причини, і 3 того часу було розроблено або модифіковано точніші показники від цих авторів, що були більш актуальними. Smith i Knight розробили індекси зносу зуба (TWI (tooth wear index)), комплексну систему, в якій всі чотири видимі поверхні (букальні, шийні, лінгвальні та оклюзійно-різцеві) всіх зубів піддалися стиранню незалежно від причини [15]. Це дозволяє уникнути плутанини, пов'язаної з термінологією, або розбіжності в думках стосовно діагностики етіології на підставі клінічних даних. Було запропоновано рекомендації щодо застосування критеріїв і стандартизації з іншими дослідниками; в разі сумніву дається найнижчий бал. Повна втрата емалі (4 бали), однак, може ввести в оману, тому що майже завжди обідки емалі зношені на поверхні країв. Цей індекс був першим, яких призначено для вимірювання та моніторингу багатофакторного зносу зуба. Існувала ще одна новаторська особливість - це здатність розрізняти прийнятні й патологічні рівні зносу. Однак деякі проблеми було виявлено з TWI, включаючи час, необхідний для застосування на всій зубощелепній системі, обсяг даних і порівняння 3 граничними рівнями для кожної вікової групи. Повне використання індексу як інструменту дослідження не є можливим без допомоги комп'ютера. Систематичний огляд від Kreulen та ін. на знос зубів у дорослих показав, що поширеність зносу зубів зростає з віком [16]. Особливий інтерес викликає клінічне вимірювання ерозій, які поширюються в дітей і підлітків. Найбільш ранні показники мають загальні, довільні критерії, спираючись на описові терміни, такі, як невелика, легка, помірна, тяжка й обширна. Restarski та ін. розробили систему класифікацій, в якій $€$ шість пунктів для оцінки тяжкості ерозивного руйнування, яке спостерігають на мовних поверхнях щурів і молярах цуценят, але існували проблеми щодо відтворюваності [17]. Кожній тварині було виділено загальний бал, який розраховували шляхом підсумовування середньої молярної оцінки в квадраті. Якщо число сильно ушкоджених зубів мале, оцінка ерозії низька, але це може маскувати значну, локалізовану клінічну проблему [18]. Eccles спочатку класифрікував ураження як незначне і прогресуюче [19]. Пізніше індекс удосконалили та розширили з великим акцентом на описових критеріях. Він був представлений як всеосяжний якісний індекс, що класифікував тяжкість і місце ерозії незалежно від промислових причин, розглядався як один з основних показників. Індекс ділиться на три класи ерозії, що визначають тип ураження на чотирьох поверхнях, і визначає поверхню, де виявили ерозію. Велику точність ввели Xhonga i Valdmanis, які розділили ерозію на чотири рівні шляхом вимірювання з пародонтальним зондом: немає, незначна (менше 2 мм), помірна (до 3 мм) і тяжка (понад 3 мм) [20]. Крім того, вони диференціювали види ерозії, згідно з морфологічними описами, як клин, блюдце, канавки і нетиповий. Bardsley й ін. вперше запропонували спрощену версію TWI при проведенні епідеміологічних досліджень великого числа підлітків у Північно-Західній Англії. Використовувалася система часткового запису, здійснювався збір даних від 40 поверхонь, включаючи оклюзійні поверхні чотирьох перших корінних зубів, та губної, різцевої і мовно-піднебінних поверхонь шести верхніх і нижніх передніх зубів [21]. Однак, незважаючи на калібрування і підготовку кадрів, виникли труднощі в діагностиці впливу дентину, встановлено, що вплив дентину не належить до значної втрати тканин зубів. Oіlo й ін. критикували використання індексів, вони застосовували нелінійний метод підрахунку балів, стверджуючи, що розраховане середнє арифметичне може бути неправильним [22]. Усі групи було розділено за ступенем ураження дентину i клінічними даними, такими, як біль, чутливість і руйнування реставрацій. Dahl та ін. модиорікували класифікацію з введенням ще більше категорій 3 метою встановлення суб'єктивних стоматологічних критеріїв для нинішніх і майбутніх оцінок зносу зубів [23]. Larsen та ін. рекомендували новий клінічний індекс, оснований на поєднанні клінічного обстеження та фотографрії зі складними якісними і кількісними критеріями [24]. Клінічно досліджували і фротографували зубний наліт перед зняттям силіконових відбитків. Вони вважали, що клінічні й фотографрічні дані доповнюють остаточну класифрікацію зносу на основі візуального огляду на × 10 збільшеннях. Існує домовленість у науковій літературі про клініко-діагностичні критерії ерозії зубів, у основному визначається як обробка канавок оклюзійної/ріжучої поверхні, дрібні дефекти на гладких поверхнях, розташованих на емалеводентинному з'єднанні та в пришийковій ділянці емалі. Ці ураження було встановлено на основі клінічного досвіду і спостережень у невеликій групі суб'єктів з відомим впливом кислот, а не систематичних досліджень [25].

\section{Висновки}

Огляд літератури за індексами на знос зубів збиває $з$ пантелику. Існує дуже багато індексів, які запропоновано і використано, з відсутністю стандартизації в термінології. $€$ багато епідеміологічних досліджень з оцінкою збільшення поширеності ураження на міжнародному рівні, оскільки результати не так легко можна порівняти. Сумнівно, що будь-який 3 використовуваних індексів досить 
чутливий для всіх випадків, також вони не можуть бути застосовані для вимірювання швидкості зносу.

Перспективи подальших досліджень. Це виклик, щоб спробувати розробити простий індекс, який можна використовувати в клінічних умовах для оцінки прогресування зносу. На сьогодні не існує ідеального індексу, який може бути застосований при проведенні епідеміологічних досліджень, а також необхідно визнати, що немає показника, щоб задовольнити всі вимоги клінічних дослідницьких груп. Знання про поточні діагностичні критерії різних фрорм зносу зубів не точні, тому є необхідність проведення подальших досліджень.

\section{Список літератури}

1. Shellis R. P. The interactions between attrition, abrasion and erosion in tooth wear / R. P. Shellis, M. Addy // Monogr. Oral Sci. - 2014. - Vol. 25. - P. 32-45.

2. Black G. V. Extracts from the last century. Susceptibility and immunity by dental caries / G. V. Black // Br. Dent J. - 1981. Vol. 151. - P. 10.

3. A clinical index for evaluating and monitoring dental erosion / I. B. Larsen, J. Westergaard, K. Stoltze [et al.] // Community Dent. Oral Epidemiol. - 2000. - Vol. 28. - P. 211-217.

4. Various substance loss defects of crowns in children: clinical observations / C. Demars, F. Gillet, Van den K. Abbeele [et al.] // Rev. Belge Med. Dent. - 1978. - Vol. 33. - P. 119-130.

5. Jaeggi T. Prevalence, incidence and distribution of erosion / T. Jaeggi, A. Lussi // Monogr. Oral Sci. - 2006. - Vol. 20. P. 44-65.

6. Grippo J. O. Erosion vs. corrosion / J. O. Grippo // J. Am. Dent. Assoc. - 2007. - Vol. 138. - P. 1535.

7. Lee W. C. Stress-induced cervical lesions: review of advances in the past 10 years / W. C. Lee, W. S. Eakle // J. Prosthet. Dent. - 1996. - Vol. 75. - P. 487-494.

8. Grippo J. O. Attrition, abrasion, corrosion and abfraction revisited: a new perspective on tooth surface lesions / J. O. Grippo, M. Simring, S. Schreiner // J. Am. Dent. Assoc. - 2004. - Vol. 135. - P. 1109-1118.

9. Lambert R. L. Abfraction--a new name for an old entity / R. L. Lambert, J. S. Lindenmuth // J. Colo Dent. Assoc. - 1994. Vol. 72. - P. 31-33.

10 Иорданишвили А. К. Клиническая стоматология : руководство для врачей / под ред. А. К. Иорданишвили. М. : Медицинская книга, 2010. - 228 с.

11. Клинические методы диагностики фрункциональных нарушений зубочелюстной системы : учеб. пособ. I И. Ю. Лебеденко, С. Д. Арутюнов, М. М. Антоник, А. А. Ступников. - М. : МЕДпресс-информ, 2006. - 112 с.

12. Современные представления о механизме развития ранней стадии повышенной стираемости зубов / Ю. В. Мандра, Г. И. Ронь, С. Л. Вотяков, Д. В. Киселева // Проблемы стоматологии. - 2011. - № 2. - С. 10-15.

13. Білоклицька Г. Ф. Основні аспекти етіології, патогенезу, клініки та лікування цервікальної гіперестезії : метод. рек. / Г. Ф. Білоклицька. - К., 2008. - 25 с.

14. Лебеденко И. Ю. Ортопедическая стоматология / И. Ю. Лебеденко, Е. А. Брагин, Э. С. Каливраджиян. M., 2015. -640 c.

15. Smith B. G. An index for measuring the wear of teeth / B. G. Smith, J. K. Knight // Br. Dent J. - 1984. - Vol. 156. - P. $435-438$. 16. Systematic review of the prevalence of tooth wear in children and adolescents / C. M. Kreulen, A. Van't Spijker, J. M. Rodriguez [et al.] // Caries Res. - 2010. - Vol. 44. - P. 151-159.

17. McCay C. M. Effects of acid beverages containing fluoride on the teeth and bones of dogs / C. M. McCay, J. S. Restarski // Fed. Proc. - 1946. - Vol. 5. - P. 147.

18. Eccles J. D. The treatment of dental erosion / J. D. Eccles // J. Dent. - 1978. - Vol. 6. - P. $217-221$.

19. Eccles J. D. Dental erosion of nonindustrial origin. A clinical survey and classification / J. D. Eccles // J. Prosthet. Dent. 1979. - Vol. 42. - P. 649-653.

20. Xhonga F. A. Geographic comparisons of the incidence of dental erosion: a two-centre study / F. A. Xhonga, S. Valdmanis // J. Oral Rehabil. 1983. - Vol. 10. - P. 269-277.

21. Bardsley P. F. Epidemiological studies of tooth wear and dental erosion in 14-year old children in North West England 1. The relationship with water fluoridation and social deprivation / P. F. Bardsley, S. Taylor, A. Milosevic // Br. Dent J. - 2004. Vol. 197. - P. 413-416.

22. An index for evaluating wear of teeth / G. Oilo, B. L. Dahl, G. Hatle, A. L. Gad // Acta Odontol. Scand. - 1987. Vol. 45. - P. 361-365.

23. The suitability of a new index for the evaluation of dental wear / B. L. Dahl, G. Oilo, A. Andersen, O. Bruaset // Acta. Odontol. Scand. - 1989. - Vol. 47. - P. 205-210.

24. A clinical index for evaluating and monitoring dental erosion / I. B. Larsen, J. Westergaard, K. Stoltze [et al.] // Community Dent. Oral Epidemiol. - 2000. - Vol. 28. - P. 211-217.

25. Ganss C. How valid are current diagnostic criteria for dental erosion? / C. Ganss // Clin. Oral Investig. - 2008. - Vol.12, Suppl. 1. - P. 41-49.

\section{References}

1. Shellis, R.P., \& Addy, M. (2014). The interactions between attrition, abrasion and erosion in tooth wear. Monogr. Oral Sci., 25, 32-45.

2. Black, G.V. (1981). Extracts from the last century. Susceptibility and immunity by dental caries. Br. Dent. J., 151, 10. 3. Larsen, I.B., Westergaard, J., Stoltze, K., Larsen, A.I., Gyntelberg F., \& Holmstrup, P. (2000). A clinical index for evaluating and monitoring dental erosion. Community Dent. Oral Epidemiol., 28, 211-217. 
4. Demars, C., Gillet, F., Van den Abbeele, K., Simonis, C., Damas, M., \& Desmedt, D. (1978). Various substance loss defects of crowns in children: clinical observations. Rev. Belge Med. Dent., 33, 119-130.

5. Jaeggi, T., \& Lussi, A. (2006). Prevalence, incidence and distribution of erosion. Monogr. Oral Sci., 20, 44-65.

6. Grippo, J.O. (2007). Erosion vs. corrosion. J. Am. Dent. Assoc., 138, 1535.

7. Lee, W.C., \& Eakle, W.S. (1996). Stress-induced cervical lesions: review of advances in the past 10 years. J. Prosthet. Dent., 75, 487-494.

8. Grippo, J.O., Simring, M., \& Schreiner, S. (2004). Attrition, abrasion, corrosion and abfraction revisited: a new perspective on tooth surface lesions. J. Am. Dent. Assoc., 135, 1109-1118.

9. Lambert, R.L., \& Lindenmuth, J.S. (1994). Abfraction - a new name for an old entity. J. Colo. Dent. Assoc., 72, $31-33$. 10. Jordanishvili, A.K. (Ed.). (2010). Klinicheskaya stomatologiya: rukovodstvo dlya vrachey [Clinical dentistry: guide for doctors.]. Moscow: Meditsinskaya kniga [in Russian].

11. Lebedenko, I.Yu., Arutyunov, S.D., Antonik, M.M., \& Stupnikov, A. (2006). Klinicheskie metody diagnostiki funktsionalnykh narusheniy zuboshchelyustnoy sistemy: Uchebnoe posobie [Clinical methods of diagnostics of functional disorders of the dental maxillofacial system: manual]. Moscow: MEDpress-inform [in Russian].

12. Mandra, Yu.V., Ron, G.I., Votyakov, S.L. \& Kiselyova, D.V. (2011). Sovremennyye predstavleniya o mekhanizme razvitiya ranney stadii povyshennoy stiraemosti zubov [Contemporary ideas about the mechanism of development of the early stage of increased erosion of teeth]. Problemy stomatologii - Problems of Stomatology, 2, 10-15 [in Russian].

13. Bylolitskaya, G.F. (2008). Osnovni aspekty etiolohii, patohenezu, kliniky ta likuvannia tservikalnoi hiperestezii [Basic aspects of etiology, pathogenesis, clinic and treatment of cervical hyperesthesia]. Kyiv [in Ukranian].

14. Lebedenko, I.Yu., Bragin, E.A., \& Kaliravadian, E.S. (2015). Ortopedicheskaya stomatologiya [Orthopedic dentistry]. Moscow [in Russian].

15. Smith, B.G., \& Knight, J.K. (1984). An index for measuring the wear of teeth. Br. Dent. J., 156, 435-438.

16. Kreulen, C.M., Van't Spijker, A., Rodriguez, J.M., Bronkhorst, E.M., Creugers, N.H., \& Bartlett, D.W. (2010). Systematic review of the prevalence of tooth wear in children and adolescents. Caries Res., 44, 151-159.

17. Mc Cay, C.M., \& Restarski, J.S. (1946). Effects of acid beverages containing fluoride on the teeth and bones of dogs. Fed. Proc., 5,147.

18. Eccles, J.D. (1978). The treatment of dental erosion. J. Dent., 6, 217-221.

19. Eccles, J.D. (1979). Dental erosion of nonindustrial origin. A clinical survey and classification. J. Prosthet. Dent., 42, 649-653.

20. Xhonga, F.A., \& Valdmanis, S. (1983). Geographic comparisons of the incidence of dental erosion: a two-centre study. J. Oral. Rehabil., 10, 269-277.

21. Bardsley, P.F., Taylor, S., \& Milosevic, A. (2004). Epidemiological studies of tooth wear and dental erosion in 14-year old children in North West England 1. The relationship with water fluoridation and social deprivation. Br. Dent. J., 197, 413-416. 22. Oilo, G., Dahl, B.L., Hatle, G., \& Gad, A.L. (1987). An index for evaluating wear of teeth. Acta. Odontol. Scand, 45, 361-365.

23. Dahl, B.L., Oilo, G., Andersen, A., \& Bruaset, O. (1989). The suitability of a new index for the evaluation of dental wear. Acta. Odontol. Scand., 47, 205-210.

24. Larsen, I.B., Westergaard, J., Stoltze, K., Larsen, A.I., Gyntelberg, F., \& Holmstrup, P. (2000). A clinical index for evaluating and monitoring dental erosion. Community Dent. Oral Epidemiol.,28, 211-217.

25. Ganss, C. (2008). How valid are current diagnostic criteria for dental erosion? Clin. Oral Investig, 12 (1), 41-49.

\title{
КЛИНИЧЕСКОЕ ИЗМЕРЕНИЕ ИНДЕКСОВ ИЗНОСА ЗУБОВ. ТЕОРЕТИЧЕСКИЙ ОБЗОР
}

А.О. Щербенко

Национальный медицинский университет имени А.А. Богомольца, г. Киев, Украина

\begin{abstract}
Истощение, эрозии и стирание проявляются в виде износа зуба. Каждая классифрикация соответствует различным процессам с конкретными клиническими признаками. Классификации, которые представлены в настоящее время, не имеют точных данных о распространенности износа зубов, поскольку индексы не всегда измеряют специфическую этиологию, или потому, что популяции исследования могут быть самыми разнообразными по возрасту и характеристикам. Износ зубов (потертость, эрозии и стирание) рассматривается на международном уровне как растущая проблема. Существуют как клинические, так и научные потребности измерить износ зуба, и в литературе описано много методов, которые можно условно разделить на количественные и качественные. Однако интерпретировать и сравнивать клинические и эпидемиологические исследования становится все труднее из-за различий в терминологии и большого числа индикаторов/показателей, которые были разработаны для диагностики, классификации и мониторинга потери твердых тканей зуба. Эти показатели разработаны с целью выявления повышения точности, но никто не имеет общего определения, что затрудняет оценку истинного увеличения распространения. В литературе определены различные показатели для использования в клинических и лабораторных условиях специфических показателей для стирания, износа, эрозии зуба.

Цель - анализ специализированной научной литературы для обобщения данных о взглядах на этиологию и методы исследования показателей стираемости зубов.

Материалы и методы. Изучили и проанализировали доступную научную литературу, посвященную особенностям этиопатогенеза, клинического течения и методам исследования показателей стираемости зубов.
\end{abstract}


Результаты. Изучив и проанализировав специализированную научную литературу, выявили, что существует много взглядов относительно этиологии и методов исследования индексов стертости зубов. Присутствуют как клинические, так и научные потребности измерить износ зуба. Не существует идеального индекса, который будет простым для использования и понимания и подсчетов критериев.

Выводы. Существует очень много индексов, которые предложены и использованы, с отсутствием стандартизации в терминологии. На сегодняшний день не существует идеального индекса, который может быть использован при проведении эпидемиологических исследований, а также необходимо признать, что не существует показателя, чтобы удовлетворить все требования клинических исследовательских групп. Текущие диагностические критерии различных форм износа зубов не точны, поэтому есть необходимость выполнения дальнейших исследований.

КЛЮЧЕВЫЕ СЛОВА: износ зуба; показатели износа зуба; стираемость; эрозии; абфракция.

\title{
CLINICAL MEASUREMENT INDICES OF TOOTH WEAR. THEORETICAL REVIEW.
}

\author{
A. O. Shcherbenko \\ O. Bohomolets National Medical University
}

Depletion, erosion, and abrasion are manifested in the form of tooth wear. Each classification corresponds to different processes with specific clinical signs. Classifications that are currently available do not have accurate data on the prevalence of tooth wear, since the indices do not always measure a specific etiology, or because the study populations can be very diverse in age and characteristics. Deterioration of teeth (abrasion, erosion and grinding) is considered at the international level as a growing problem. There are both clinical and scientific needs to measure the wear of the tooth, and literature fades with many methods that can be conditionally divided into quantitative and qualitative. However, interpreting and comparing clinical and epidemiological studies is becoming increasingly difficult due to differences in terminology and a large number of indicators / indicators that have been developed to diagnose, classify and monitor the loss of hard tooth tissues. These indicators were designed to identify an increase in accuracy, but no one has a general definition, which makes it difficult to estimate the true increase in spread. In the literature, various indicators have been determined for the use in specific clinical and laboratory conditions of specific indicators for erasure, wear and tooth erosion.

Aim - to analyze the specialized scientific literature for summarizing data on views on the etiology and methods for examining the indicators of tooth erosion.

Materials and Methods. We studied and analyzed the available scientific literature, which is devoted to the peculiarities of etiopathogenesis, clinical course and methods of studying the indicators of tooth erosion.

Conclusions. There are a lot of indices that are proposed and used, with the lack of standardization in terminology. To date, there is no ideal index that can be used to conduct epidemiological studies, and it must also be recognized that there is no indicator to meet all the requirements of clinical research groups. The current diagnostic criteria for various forms of tooth wear are not accurate, so there is a need for further research.

KEY WORDS: tooth wear; tooth wear indices; attrition; erosion; abfraction.

Рукопис надійшов до редакції 14.06.2017 p.

\section{Відомості про авторів:}

Щербенко Аліна Олегівна - аспірант кафредри ортопедичної стоматології Національного медичного університету імені О.О. Богомольця.; тел. 8093-235-31-08 